\title{
Injuries at the BMX Cycling European Championship, 1989
}

\author{
T. Brøgger-Jensen MD, I. Hvass MD and S. Bugge MD \\ Department of Orthopaedic Surgery, Aalborg Hospital, Denmark
}

\begin{abstract}
At the BMX Cycling European Championship in 1989 with 976 participants of both sexes, aged between six and 40 years, all injuries were registered. A total of $6.3 \%$ of the participants sustained injuries (1.6\% per individual start), $52.5 \%$ required medical attendance and $3.3 \%$ necessitated hospital admission. Women were injured twice as frequently as men. Most injuries, $72.1 \%$, were minor, $6.6 \%$ were fractures with $75 \%$ of the fractures affecting the upper limbs. BMX bicycle riding has the high injury risk of 1190 injuries per 1000 competition hours.
\end{abstract}

Keywords: BMX bicycle injuries, sports epidemiology, competition

\section{Introduction}

BMX bicycle riding is a fairly new sport in which the Western World has shown increasing interest. There are $21 \mathrm{BMX}$ clubs in Denmark, organising well over 30 races annually.

Previous publications of $\mathrm{BMX}$ injuries have mainly dealt with injuries sustained on public roads ${ }^{1-7}$.

The object of this study is to assess the pattern of injury found at the BMX Cycling European Championship held in Denmark in 1989, especially as regards to type, sex, and age distribution, to discuss possible preventive measures, and to relate the risk of injury to other big Danish sports meetings.

\section{Materials and methods}

The BMX Cycling European Championship was held in Denmark at the BMX Stadium in the town of Aalborg on 8 and 9 July 1989. Altogether there were 976 participants, 814 men and 162 women, ranging in age from 6 to 40 years. The participants were divided into classes according to age and sex. During the 2 days of this event there were 540 heats, each with between six and eight participants. This corresponds to 3843 individual starts with an average heat time of 48 seconds. The length of the race track was 350 metres, and the track had a stable gravel surface with various obstacles in the form of low hills, jumps and

Address for correspondence: Torben Brøgger-Jensen, Department of Orthopaedic Surgery, Aalborg Hospital, Southern Section, 18-22 Hobrovej, Dk-9100 Aalborg, Denmark

(C) 1990 Butterworth-Heinemann Ltd 0306-3674/90/040269-02 bends. The track was raced through once in each heat.

Crashes, often involving several participants, occurred frequently. Injuries were sustained through impact on the track and/or collision with the rider's own or other competitors' bicycles.

There was a first-aid tent, manned by four members of the local Red Cross branch. A doctor was constantly present. All injuries were registered. Those requiring further treatment or radiographs were referred to the local casualty department. Injuries were collated from case sheets from the casualty department and notes taken by the doctor in attendance at the stadium. Only injuries sustained during the $B M X$ race meeting are included.

\section{Results}

The total number of injuries registered was 61 (Table 1). Thus, $6.3 \%$ of the participants were injured, (1.6\% per individual start). Of all registered injuries, $47.5 \%$ were dealt with by the first-aiders alone, the remaining $52.5 \%$ required medical attention and $16.7 \%$ of these required examination at the hospital. Altogether, $3.3 \%$ of those injured were admitted. The incidence of injury for women was almost twice that for men (2.5\% per individual start as against $1.4 \%)$. There was no significant age difference in the injury incidence.

Excluding abrasions, $31.4 \%$ of injuries affected the upper limbs and $37.1 \%$ the lower. Fractures formed $6.6 \%$ of total injuries (clavicle (two), humerus (one), ilium (one)).

Table 1. Type of injury

\begin{tabular}{lrr}
\hline & Number & Per cent \\
\hline Abrasions & 26 & 42.6 \\
Contusions & 18 & 29.5 \\
Sprains & 8 & 13.1 \\
Fractures & 4 & 6.6 \\
Concussion & 2 & 3.3 \\
Tooth injuries & 1 & 1.6 \\
Other & 2 & 3.3 \\
Total & 61 & 100.0 \\
\hline
\end{tabular}




\section{Discussion}

As a safeguard against accidents, the individual participant in BMX race meetings in Denmark has to wear a helmet, gloves and elbow pads, but there are no requirements concerning clothing/trousers. Abrasions $(42.6 \%)$ and contusions $(29.5 \%)$ were the commonest injuries. More stringent requirements relating to the clothing worn by riders would probably reduce the occurrence of those types of injury. Two cases of concussion occurred despite participants' compulsory use of safety helmets.

The incidence of injury for women $(9.4 \%)$, corresponding to $2.5 \%$ per individual start, is almost twice that for men $(5.6 \%)$, corresponding to $1.4 \%$ per individual start. Difference in physique may to some extent account for this increased incidence.

The calculations from this study, an injury rate of 1190.48 injuries per 1000 competition hours, compares with, for example, soccer injuries in Danish youths: $19.1^{8}$ and Aarhus Marathon 1986: 89.4 injuries $/ 1000$ competition hours respectively ${ }^{9}$.

\section{References}

1 Illingworth, C.M. BMX compared with ordinary bicycle accidents Arch Dis Child 1985, 60, 461-464

2 Illingworth, C.M. Injuries to children riding BMX bikes $\mathrm{Br}$ Med $J$ 1984, 289, 956-957

3 Worrel, J. BMX bicycles: accident comparison with other models Arch Emerg Med 1985, 2, 209-213

4 Park, K.G.M. and Dickson, A.P. BMX-bicycle injuries in children Injury 1986, 17, 34-36

5 Sparnon, T., Moretti, K. and Sach, R.P. BMX handlebar, a threat to manhood? Med J Aust 1982, 2, 587-588

6 Soysa, S.M., Grover, M.L. and McDonald, P.J. BMX bike injuries: the latest epidemic $\mathrm{Br}$ Med J 1984, 289, 960-961

7 Spanon, A. Letter to Editor Br Med J 1984, 289, 1226-1227

8 Schmidt-Olsen, S., Bünemann, L.K.H., Lade, V. and Brassøe, J.O.K. Soccer injuries of youth $\mathrm{Br} J$ Sports Med 1985, 19, $161-164$

9 Jakobsen, B.W., Krøner, K., Schmidt, S.A. and Jensen J. Løbeskader ved motionsmarathon Uge Skr Lxger 1989, 151, 2189-2192

\title{
The Society of Apothecaries of London
}

\author{
Diploma in Sports Medicine \\ 25th May and 5th June, 1990
}

The following candidates have satisfied the Examiners:

Ivor Daniel Baron, M.B., Ch.B. Wales, D.R.C.O.G.

Roderick David Jaques, M.B., B.S. Lond., D.R.C.O.G., M.R.C.G.P.

Deanna Christine Jennings, M.B., B.S. Lond., L.R.C.P. Lond., M.R.C.S. ENG.

Domhnall MacAuley, M.B., B.Ch. N.U.I., B.A.O., D.R.C.O.G., M.R.C.G.P., M.I.C.G.P.

Nicola Maffulli, M.D. Naples, Dip. Orthop.

Conor Patrick O'Brien, M.B., B.Ch. N.U.I., B.A.O., L.R.C.P.S.I.

Andrew Graeme Robertson, M.B., Ch.B. Aberd., D.R.C.O.G., D.A., M.R.C.G.P.

D.H.C. Barrie

(Registrar) 